\title{
REPOSISI PARADIGMA TERHADAP ALAM SEMESTA: TAWARAN REFLEKSI FILOSOFIS DAN TEOLOGIS
}

\author{
Edy Syahputra Sihombing \\ Dosen Filsafat Universitas Katolik Parahyangan Bandung
}

\begin{abstract}
The civilization of human life is formed as inseparable from human relations with the universe. Science has emerged through human relations with the universe. Human culture and tradition are also formed through human relationship with nature. Moreover, human religious imagination is formed through human relations with the universe. Briefly, humans live and develop themselves from and in the universe. In early time, humans interpreted themselves as a part of the universe and united with the universe that humans could not live without. Yet, in line with the development of science and human civilization, human perspective on the universe also changes. The universe tends to be regarded as an object which can be exploited for the sake of human needs. In the end, environmental damage that also takes a lot of victims is a consequence of human behavior. The holistic and relational paradigm of the universe as well as philosophical and theological reflections offer to reinterpret the sacredness of the universe with the aim of improving human relations with the universe which tends to be anthropocentric.
\end{abstract}

KEYWORDS: universe, environment, exploitation, domination, holistic paradigm, philosophical reflection, theological reflection, ecocentric ethics.

ABSTRAK: Peradaban hidup manusia terbentuk tidak lepas dari relasi manusia dengan alam semesta. Ilmu pengetahuan bermunculan melalui relasi manusia dengan alam semesta. Kebudayaan dan adat-istiadat manusia juga terbentuk melalui relasinya dengan alam. Bahkan imajinasi religius manusia juga terbentuk melalui relasi manusia dengan alam 
semesta. Singkatnya, manusia hidup dan mengembangkan diri dari dan di dalam alam semesta. Sejak awal manusia memaknai dirinya sebagai bagian dari alam semesta dan bersatu dengan alam semesta yang tanpanya manusia tidak bisa hidup. Akan tetapi dengan berkembangnya ilmu pengetahuan dan peradaban manusia, cara pandang manusia terhadap alam semesta turut berubah. Alam semesta cenderung dipandang sebagai objek yang dapat begitu saja dieksploitasi demi kebutuhan manusia. Akhirnya kerusakan lingkungan hidup yang juga memakan banyak korban menjadi konsekuensi atas perilaku manusia. Paradigma holistik dan relasional terhadap alam semesta serta refleksi filosofis dan teologis hendak memberikan tawaran untuk kembali memaknai sakralitas alam semesta dengan tujuan memerbaiki relasi manusia dengan alam semesta yang cenderung bersifat antroposentris.

KATA-KATA KUNCl: alam semesta, lingkungan hidup, eksploitasi, dominasi, paradigma holistik, refleksi filosofis, refleksi teologis, etika ekosentris.

\section{Manusia dan Alam Semesta}

Manusia hidup dari dan di dalam alam semesta. Kesadaran ini muncul oleh karena manusia mempunyai ketergantungan erat dengan alam semesta yang tanpanya manusia tidak bisa hidup. Ketergantungan manusia terhadap alam semesta diibaratkan seperti bayi yang lahir dan dibesarkan oleh ibunya. Ibu yang merawat, menyusui, memberi makan, bahkan turut berandil besar dalam membentuk karakter bayi yang lahir hingga bertumbuh dewasa. Alam semesta ibarat sang ibu yang terusmenerus memberikan kasih sayang dan merawat bayi yang dilahirkan melalui dan dalam diri sang ibu. Sama halnya dengan sang bayi, hidup manusia bergantung pada alam semesta yang telah memberikan diri bagi manusia, sehingga manusia dapat hidup dan berkembang.

Perkembangan peradaban manusia terbentuk melalui relasi yang intim dengan alam semesta. Manusia mulai mengembangkan diri dan membentuk kebudayaan, adat-istiadat, serta perangkat-perangkat kehidupan, tidak lepas dari latar belakang geografis dan situasi 
lingkungan di mana ia hidup. Bahkan siapa itu manusia juga dibentuk di dalam dan melalui lingkungan hidup yang ada di sekitarnya. Artinya, manusia tidak dapat hidup terisolasi, manusia makhluk yang melulu terkoneksi, begitu juga dengan lingkungan hidupnya. ${ }^{1}$ Penemuanpenemuan palaeontologi membuktikan bahwa manusia sejak awal membentuk pola kehidupan melalui relasinya dengan alam semesta. Manusia-manusia purba tidak lepas dari kegiatan berburu untuk dapat memenuhi hidupnya. Dalam perkembangan selanjutnya, manusia purba mulai bercocok tanam untuk memenuhi kebutuhan hidupnya. Singkatnya, kehidupan manusia bergantung kuat pada lingkungan di mana ia hidup dan tinggal.

Relasi manusia dengan alam semesta juga menjadi dasar terbentuknya imajinasi religius dan perasaan religius manusia. Sejalan dengan ide Bonaventura, ciptaan dan segala isinya membuat manusia dapat mengenal yang ilahi. ${ }^{2}$ Dengan kata lain, dari alam dan di dalam alam, manusia mengenal Tuhan. Manusia-manusia primitif atau manusia purba tidak hanya bergantung pada alam semesta dalam perkara yang bersifat fisikal. Manusia mulai mengenal realitas tertinggi yang melebihi kemampuan dirinya melalui kedekatannya dengan alam semesta. Pertama-tama manusia mengenal adanya kekuatan yang mahadahsyat di luar dirinya melalui kedekatannya dengan alam semesta. Manusia mulai mengenali realitas ilahi yang dipercaya melalui kehadiran alam semesta yang memberi manusia kehidupan. Aktivitas yang muncul setelah manusia menyadari adanya kekuatan yang ilahi di luar dirinya adalah manusia mulai menyembah dengan berbagai macam bentuk ritus-ritus simbolik. Contoh sederhana yang dapat kita temukan adalah manusia purba dahulu kala menyembah pohon-pohon besar, atau menyembah benda-benda lain yang dianggap sakral dan dianggap mampu

\footnotetext{
1 Pavithran, A Textbook of Environmental Economics (New Delhi: New Age International Publishers, 2008), 2.

2 Robert Imperato, Early and Medieval Christian Spirituality (Lanham, MD: University Press of America, 2002), 60.
} 
memberikan pertolongan dan kehidupan bagi mereka. ${ }^{3}$

Relasi manusia dengan alam semesta sejak awal mempunyai aspek sakralitas yang dalam diri manusia tidak hanya menemukan kehidupan di dalam dan melalui alam semesta, melainkan juga menemukan bahwa di balik alam semesta yang memberikan kehidupan, manusia juga menemukan adanya kekuatan yang ilahi yang dianggap sebagai pemberi kehidupan dan pencipta alam semesta. Manusia purbakala memahami bahwa alam semesta dengan segala isinya adalah manifestasi dari kekuatan yang ilahi sang pemberi kehidupan. Oleh karenanya manusia purbakala menjalin relasi dengan alam semesta berdasarkan keyakinan bahwa alam semesta menyimpan kekuatan yang ilahi. ${ }^{4}$ Konsekuensinya adalah manusia purba menaruh sikap hormat yang tinggi terhadap alam semesta yang senantiasa memberikan kehidupan. Oleh karena itu dapat dikatakan manusia dan alam semesta sejak awal membentuk relasi yang mendalam dalam setiap dinamika aktivitas manusia dan membuat manusia sadar bahwa hidup manusia bergantung pada alam.

Hakikat alam semesta berubah dan menjadi, atau apa yang ada di alam ini tidak hanya sekadar ada, melainkan berada dalam proses menjadi. ${ }^{5}$ Demikian juga manusia, turut dalam perubahan, baik cara hidup, cara berpikir maupun cara berada. Namun, perubahan itu pada dasarnya netral, artinya perubahan bahkan bisa dimanfaatkan, dimanipulasi, bahkan dibuntungi. Rupanya dalam kaitannya dengan alam semesta, manusia mengalami perubahan yang mahadahsyat namun melenceng dari ritme perubahan dengan alam semesta. Perbedaan perubahan antara alam dan manusia terletak dalam daya ubahnya.

3 Bdk. Karen Armstrong, Masa Depan Tuhan: Dalam bagian satu Homo Religiosus (terj.) (Jakarta: Mizan, 2011).

4 Bdk. Fred Hoyle, Facts and Dogmas in Cosmology Elsewhere (Cambridge, England, New York: Cambridge University Press, 1982), 13-4.

5 Herakleitos (500 SM) meyakini bahwa realitas tertinggi (Ultimate Reality) merupakan sesuatu yang terus-menerus berjalan dalam perubahan, begitu juga dengan alam semesta beserta isinya termasuk manusia. Pemikir modern seperti Fritjof Capra juga meyakini bahwa realitas mengalir dan berada dalam proses menjadi dan perubahan terus menerus (Flux). Lih. Richard G. Geldard, Remembering Heraclitus (Edinburgh: Floris Books, 2000). 
Gunung berapi meletus bukan sekadar bencana tetapi juga proses perubahan tanah yang menjadi lebih subur dan baik, akan tetapi pemberian pupuk kimia terus-menerus pada tanah justru dapat membuat tanah jenuh dan tidak lagi dapat memberi hasil yang terbaik dari tanah. Ada beda daya ubah. Dalam kaitannya dengan alam semesta, perubahan manusia justru hanya berkiblat ke arah dominasi, sehingga alam ini tidak lagi dianggap sebagai sesuatu yang sakral dan terkait dengan manusia. Gaya hidup berubah dari paradigma sakralitas terhadap alam menjadi vandalisme yang bengis. Hidup sekadar pertarungan mendapatkan sebanyak mungkin yang bisa diperas dari alam tanpa menghargai alam itu lagi. Di dalam pertarungan itu manusia sesungguhnya lelah dan jenuh atas kemacetan, polusi, lahan yang semakin sempit, harga tanah yang terus melonjak, yang membuat tidak sedikit orang menyerah dan tak mampu lagi mengejar tantangantantangan perubahan. Akhirnya era ini hanya afirmasi adekuat atas gagasan Charles Darwin, tentang siapa yang kuat dialah yang menang. ${ }^{6}$

Herakleitos (500 SM) sudah lama sekali meyakini bahwa hakikat alam semesta itu adalah perubahan dalam proses menjadi. Perubahan yang yang ditawarkan alam adalah semua berjalan menuju kesempurnaan bagi seisi alam semesta ini. Perubahan manusia, meskipun di satu sisi dapat menjadi bumerang bagi manusia itu sendiri, tetapi di sisi lain perubahan adalah anugerah dan berkat kreativitas yang tanpa batas dari hasil karya manusia. Akan tetapi nature mendahului culture, artinya kodrat manusia sebagai makhluk alam menuntut pertimbangan mendalam atas perubahan diri dalam menentukan perilaku dan sikap terhadap alam semesta. Perubahan itu juga berasal dari embrio ilmu pengetahuan yang melahirkan paradigma dominatif.

\section{Alam Semesta dan IImu Pengetahuan}

Sejarah peradaban manusia membuktikan bahwa manusia mengalami

6 Bdk. Martin Harun, Ensiklik Laudati Sri Paus Fransiskus (terj.) (Jakarta: Obor, 2015), 15. 
proses perkembangan, dalam aspek sosial, ekonomi, kebudayaan, serta berbagai aspek kehidupan lainnya. Demikian juga halnya dalam bidang ilmu pengetahuan. Sebelumnya, kerangka berpikir manusia dalam relasinya dengan alam semesta dilandasi dengan cara berpikir mitologis. Seiring berjalannya waktu, cara berpikir mitologis dianggap tidak lagi memadai, sebab kerangka berpikir mitologis tidak dapat menjelaskan seluruh aspek alam semesta. Oleh karena itu, muncul berbagai upaya untuk menjelaskan alam semesta melalui kerangka berpikir logis. ${ }^{7}$ Mulai sejak itu ilmu pengetahuan mulai bermunculan. Dalam sejarah filsafat, ilmu pengetahuan dirangsang oleh rasa ingin tahu akan hakikat alam semesta. Pertanyaan inilah yang mendorong lahirnya ilmu pengetahuan. Ilmu pengetahuan kemudian membentuk peradaban manusia yang semakin lebih berdaya guna, terutama dalam mengolah alam sekitar. Berbagai jenis ilmu pengetahuan yang mulai bermunculan tidak lepas dari relasi manusia dengan alam semesta. Para filsuf pertama Yunani, seperti Thales, Anaximandros, Anaximenes, Pithagoras, dan lain sebagainya juga memulai permenungan yang melahirkan ilmu pengetahuan melalui alam semesta.

Proses perjalanan perkembangan filsafat alam mengalami tiga tahap perubahan. Pertama, adalah tahap para filsuf alam. Aristoteles adalah tokoh utama dalam fase ini. Aristoteles memahami alam semesta secara organis sebagai sebuah kesatuan utuh tak terpisah antara satu dan yang lainnya. Tahap ini bersandar pada pemahaman bahwa manusia hidup dan mengalami alam dalam relasinya yang bersifat organis dengan seluruh elemen alam semesta. Belum tampak pemisahan yang tegas antara manusia sebagai makhluk yang berakal budi dan alam semesta. Atmosfer yang kuat pada masa ini adalah tidak ada pemisahan antara akal budi dan iman, bahkan dipahami berperan secara simultan sehingga menghantar manusia pada pengetahuan yang utuh tentang alam semesta. Pandangan ini, diperkokoh oleh Thomas Aquinas yang

7 Kees Bertens, Sejarah Filsafat Yunani (Yogyakarta: Kanisius, 1999), 21-3. 
berjuang menjadikannya sebagai kerangka ilmu pengetahuan atau filsafat alam. Pada tahap ini manusia diposisikan melalui relasinya dalam kesatuan yang utuh dan menyeluruh bersama alam yang menarik manusia pada perasaan kagum, rasa terpesona, bahkan ketakutan di hadapan alam semesta. Kekuatan ilahi dirasakan muncul dari rangsangan rasa tersebut, sehingga akal budi tak mampu menolak pancaran kekuatan yang dahsyat melalui alam semesta. Dengan kata lain, ilmu pengetahuan tentang alam berangkat dari keterkaitan erat atas fenomena alam dan rasa hormat akal budi terhadap rasa yang muncul melalui pengalaman dengan alam semesta. Fase ini menempatkan kesatuan kemampuan akal budi, spiritual, moral dan perasaan di hadapan alam semesta. Jejak pengalaman manusia purba masih tersirat dalam fase ini meskipun akal budi telah muncul sebagai sumber ilmu pengetahuan, akan tetapi ditempatkan dalam ketaatan iman yang muncul dari tumpahan rasa takjub atas fenomena alam semesta. ${ }^{8}$

Tahap kedua ditandai dengan munculnya abad Pencerahan. Pada tahap ini terjadi banyak perubahan paradigma, baik dari sisi ilmu pengetahuan maupun relasi manusia dengan alam semesta. Paradigma organis tentang alam semesta perlahan ditinggalkan. Cara pandang yang mendominasi pada tahap ini adalah paradigma mekanistis tentang alam semesta. Di dalam proses perubahan paradigma organistis menuju mekanistis terkandung perubahan nilai yang mendominasi ilmu pengetahuan dan peradaban dunia. Cara pandang mekanistis dipengaruhi oleh Rene Descartes (1596-1650). Pengaruh Descartes cukup kuat dalam perkembangan filsafat Barat, baik dalam ilmu pengetahuan maupun peradaban. Rumusan Cogito Ergo Sum ${ }^{9}$ (saya berpikir maka saya

\footnotetext{
8 Fase perkembangan ini disadur dari Fritjof Capra, The Turning Point: Science, Society and the Rising Culture (London: Flamingo, 1983).

9 Descartes disebut-sebut sebagai bapak filsafat modern. Filsafat modern diterjemahkan dalam karakter Clara et Distincta. Pernyataan itu bermakna bahwa realitas bisa dijelaskan secara jelas, lugas dan bisa dibedakan antara yang satu dan yang lain oleh kesadaran akal budi atau pikiran manusia. Dengan demikian, zaman modern itu ditandai oleh kebangkitan
} 
ada) yang keluar dari buah pemikiran Descartes merasuki cara berpikir Barat, baik tentang diri manusia maupun tentang alam semesta. Tahap ini adalah tahap perayaan akal budi. Akal budi menjadi dasar dan sumber pengetahuan, sehingga sisi lain seperti tubuh, intuisi, perasaan cenderung dikesampingkan. Singkatnya, validitas kebenaran berangkat dari penalaran akal budi, atau pengetahuan yang valid adalah pengetahuan rasional. Di sisi lain pada masa itu telah muncul pengetahuan empiris yang berkeyakinan bahwa pengalaman adalah dasar pengetahuan yang kokoh dan benar, akan tetapi pengaruh Descartes cenderung lebih kuat.

Paradigma mekanistis berpengaruh terhadap cara pandang manusia atas alam semesta. Dalam cara pandang rasionalitas, manusia adalah makhluk yang berakal budi dan menjadi dasar pengetahuan, konsekuensinya, bentuk yang tidak termasuk dalam makhluk berakal budi dianggap lebih rendah. Alam semesta dianggap tidak mempunyai kemampuan akal budi, artinya lebih rendah dari manusia, dan celakanya cenderung tidak dianggap mempunyai nilai dalam dirinya sendiri. Alam semesta dalam cara pandang tahap ini diidentikkan dengan tubuh yang bekerja secara mekanistik. Alam semesta dan bagian-bagiannya hanya berfungsi secara mekanistik. Pandangan dualisme pada masa Pencerahan tegas tersirat. Ada pemisahan antara tubuh dan jiwa, sehingga melahirkan pemahaman bahwa alam bergerak berdasarkan sistem mekanistik dalam bagian-bagian yang terpisah yang interaksinya dianggap menentukan fenomena alam.

Atmosfer tahap ini berada dalam genjotan revolusi ilmu pengetahuan yang berangkat dari dasar validitas rasional. Karakternya adalah pemisahan atau dualisme. Ilmu pengetahuan berubah arah dari awalnya berusaha memahami tatanan alam yang harmonis dan organis menjadi instrumen untuk mendominasi dan menguasai alam. Perubahan 
cara pandang dalam ilmu pengetahuan dan filsafat pada abad 16-17 dominan dipengaruhi oleh pemikiran Descartes. Metode dasar yang ditawarkan oleh Descartes adalah metode keraguan atau kesangsian radikal (radical doubt) terhadap segala sesuatu. Pengetahuan yang valid dan benar diperoleh dengan meragukan segala sesuatu, termasuk juga meragukan bentuk-bentuk pengetahuan lainnya. Dengan keraguan, manusia dapat sampai pada pengetahuan yang clara et distincta (jelas dan dapat dibedakan, dipilah-pilah). Hal yang tidak dapat diragukan hanyalah kenyataan bahwa manusia sedang berpikir; ketika manusia menyadari bahwa ia sedang berpikir, maka itu dianggap sebagai kebenaran mutlak, tak dapat disangkal lagi, sebab meragukan bahwa saat ini saya sedang berpikir adalah kontradiksi. Konsekuensinya, dengan kebenaran yang tak dapat diragukan adalah manusia yang berpikir, maka manusia direduksi dalam tatanan rasionalitas akal budi. Konsekuensi lain adalah, bagian diri manusia yang lain dianggap lebih rendah dibanding akal budi. Tubuh, aspek intuitif, perasaan, dianggap lebih rendah dan dianggap tidak rasional dan karenanya tidak dapat menghantar sampai pada kebenaran ilmiah. Sikap ini memunculkan anggapan bahwa materi lebih rendah dari akal budi. Selanjutnya muncul pemahaman diri manusia sebagai subjek di hadapan alam semesta yang dianggap sebagai objek, materi yang tak berakal budi, tak mempunyai roh. Juntrungannya sampai pada pemahaman dan perilaku manusia terhadap alam semesta: itu diukur dari perspektif manusia yang menganggap alam sebagai objek pemenuhan kebutuhan manusia.

Model pemahaman rasionalitas yang berorientasi pada akal budi yang berpikir melahirkan model lain untuk sampai pada pengetahuan adalah model empiris. Dalam metode empiris, pengalaman dianggap sebagai dasar dan sumber pengetahuan. Akan tetapi model ini juga mengubah arah tujuan ilmu pengetahuan yang tadinya berusaha untuk memahami tatanan alam semesta dalam relasinya satu dengan yang lain 
menjadi dominasi terhadap alam semesta. Di sini pengetahuan menjadi kekuatan; meminjam Bacon, "Knowledge is Power". ${ }^{10}$ Dengan ilmu pengetahuan dan perkembangan teknologi, manusia cenderung berfokus pada eksploitasi alam dan menjadikannya sebagai objek pemenuhan kebutuhan manusia.

Perkelahian antara rasionalisme dan empirisme ditangkap oleh Isaac Newton yang berupaya untuk menggunakan kedua model itu sebagai sumber pengetahuan. Akan tetapi, dasar pemikiran mekanistik alam semesta tidak berubah. Newton juga mengikuti Descartes yang menganggap alam semesta sebagai mesin raksasa yang bergerak dengan hukum-hukum yang pasti dan tetap. Dengan demikian, seluruh gerak alam semesta dapat diprediksi dan dijelaskan dalam rangkaian sebabakibat. Paradigma mekanistis Descartes dan Newton juga berpengaruh pada bidang keilmuan lainnya. Bidang biologi, misalnya, juga memandang organisme sebagai mesin dalam struktur yang terpisahpisah. Mengikuti cara pandang ini, organisme dapat dipahami dan direduksi menjadi bagian-bagian kecil. Keberhasilan paradigma mekanistik dalam memengaruhi biologi memunculkan dogma bahwa hukum biologi dapat disesuaikan dengan hukum fisika dan kimia. Sehingga muncul buku yang menghebohkan karangan Julien de La Mettrie, Man a Machine, yang memandang manusia sekadar sebagai mesin dengan hukum-hukum yang dapat diprediksi dan tetap. ${ }^{11}$

Perubahan cara pandang yang terdapat dalam bidang fisika, biologi, dan matematika yang memperlebar paradigma mekanistik, berpengaruh juga dalam tatanan ilmu sosial. Misalnya, John Locke juga menggunakan paradigma atomistik Newton untuk memahami realitas sosial dalam masyarakat. Menurut John Locke, karakter masyarakat dapat dilihat dan dirujuk dari pola perilaku individu yang juga turut

\footnotetext{
10 A. Sonny Keraf, Filsafat Lingkungan Hidup: Alam Sebagai Sebuah Sistem Kehidupan (Yogyakarta: Kanisius, 2014), 33.

11 Fritjof Capra, The Web of Life: A New Scientific Understanding of Living Systems (New York: Anchor Books: 1996), 20.
} 
membentuk masyarakat. Bahkan, Locke mengikuti Thomas Hobbes yang mengatakan bahwa manusia mempunyai kecenderungan untuk menghisap dan memangsa manusia lainnya. Kecenderungan ini hanya dapat dikontrol oleh kesepakatan dalam bentuk lembaga yang mempunyai otoritas dan kekuasaan serta hukum yang kuat untuk menjamin keteraturan dan keamanan bagi seluruh individu dan tatanan masyarakat. Pola ini mengacu pada pola mekanistik Newton dan Descartes tentang alam semesta. ${ }^{12}$

Pertanyaannya, siapa yang bertanggung jawab atas kerusakan lingkungan hidup? Cara pandang mekanistik turut andil memengaruhi tatanan ekonomi yang cenderung mendorong manusia hidup konsumtif. Kemajuan teknologi dapat dipandang sebagai berkat dan juga perayaan atas rasionalitas serta karya kreatif manusia, akan tetapi juga dapat menjadi bumerang bagi manusia. Kemajuan ilmu pengetahuan dan teknologi memengaruhi sistem ekonomi dalam hal permainan hasrat konsumen. Pembaharuan sebagai daya inovasi nalar manusia dalam ilmu pengetahuan dan teknologi merangsang hasrat manusia untuk terus mengejar kebaruan tersebut, yang akhirnya memunculkan mentalitas habis pakai buang atau out of mode. Kebutuhan produsen meningkat, hasrat konsumen akan kebaruan dikontrol dan ketakutan atas keterbatasan sumber daya alam mulai muncul.

Mengambinghitamkan sistem ekonomi yang dipaksa oleh kemajuan ilmu pengetahuan dan teknologi adalah tidak adil. Perkara ekologis lebih tepat disebut sebagai perkara manusia-manusia kelas atas, borjuis, dan pemodal yang mulai melihat adanya kekurangan bahan produksi. Rangkaian penyebab kait-mengait satu sama lain, dan akar masalah yang cenderung tak tampak adalah pergeseran cara pandang manusia terhadap alam semesta. Masalah ini juga rentan terjadi dalam diri setiap manusia, lepas dari kelas kehidupan mereka. Pergeseran cara pandang manusia dari organistik ke mekanistik mendorong manusia

12 Sonny Keraf, Filsafat Lingkungan Hidup, 64. 
melakukan demitologisasi, artinya cara berpikir mitologis dan makna yang terkandung di dalamnya tak lagi memadai dan cara berpikir logis menjadi jawaban. Hasrat demitologisasi mendorong manusia untuk menelanjangi alam sebagai objek yang diukur dari aspek kebutuhan manusia. Manusia mulai membedakan diri dengan alam semesta, bermuara pada membuat jarak dengan alam dan melakukan gradasi pada alam sehingga alam ada sebatas untuk kebutuhan manusia. Akhirnya, alam semesta dipahami sebagai sesuatu yang tak bernilai dalam dirinya sendiri kecuali dari sisi manusia.

Inilah cara pandang yang menjadi akar krisis manusia modern dan juga menjadi pemicu krisis ekologis yang menyebabkan kerusakan lingkungan hidup, bahkan bencana alam. Cara pandang ini melahirkan sikap eksploitatif demi kebutuhan manusia sebab alam cenderung dipandang lebih rendah dari manusia, dan manusia memosisikan diri sebagai subjek di luar alam dalam sistem mekanistik. Sehingga, juntrungannya, manusia zaman ini seolah kehilangan cita rasa kesatuan dengan alam semesta dengan melihat alam semesta sebagai sistem mekanistis dari paradigma dualistis dan antroposentris.

Perkara ekologis dan kerusakan lingkungan hidup tidak bisa dilepaskan dari pola kehidupan manusia dalam aspek ilmu pengetahuan, ekonomi, sosial, politik, dan kebudayaan. Perubahan dan kemajuan pesat dalam ilmu pengetahuan terutama dalam bidang teknosains, memberikan dampak baik untuk kehidupan manusia. Patut disyukuri dan dirayakan bahwa dengan kemampuan ilmu pengetahuan dan teknosains, manusia banyak terbantu untuk menjalani dinamika hidup. Akan tetapi, kemajuan teknosains seperti pedang bermata dua. Ia dapat menghantar manusia pada dilema (persimpangan jalan). Artinya, kemajuan mengandung anasir destruktif bagi manusia dan alam semesta, oleh karena kreativitas rupanya menawarkan kekuasaan. Dengan kata lain, daya kreativitas manusia melalui pengetahuan dan perkembangan teknosains menawarkan kekuasaan dan dominasi manusia, bukan hanya pada sesamanya tetapi juga alam semesta. 
Kekuasaan yang ditawarkan oleh ilmu pengetahuan dan teknosains rupanya tak sekadar memberi dampak kebaikan bagi kehidupan manusia. Kekuasaan itu kemudian ditafsirkan sekadar dominasi dalam proses pengaliran dari pusat ke setiap sendi atau sekadar proses dari atas ke bawah yang sifatnya dominatif dan posesif. Mental kekuasaan macam ini juga dipupuk dalam oleh ilmu pengetahuan. Mental kekuasaan ini yang kemudian dikritik oleh Foucault. Mental kekuasaan demikian tidak memberi jaminan bahwa kekuasaan akan selalu digunakan dengan baik. Maka Foucault berikhtiar memutar balik makna kekuasaan macam itu. Foucault mengatakan bahwa kekuasaan itu harusnya bersifat produktif, bukan dominatif atau posesif. ${ }^{13}$ Faktanya, teknosains juga menawarkan kekuasaan yang destruktif. Celakanya, kemajuan ilmu pengetahuan dan teknosains tidak dibarengi nilai-nilai moral yang menyentuh hati nurani dan nilai-nilai dasar serta tanggung jawab kebebasan. Bahkan pendidikan tentang moralitas dan nilai-nilai dasar cenderung dianggap sekunder dalam kancah dunia pendidikan. Singkatnya, kebebasan manusia untuk mengumbar daya cipta dengan landasan ilmu pengetahuan yang menawarkan kekuasaan dapat memunculkan dampak destruktif bagi tatanan kehidupan.

\section{Dominasi dan Dehumanisasi}

Kodrat manusia adalah makhluk yang hidup dari dan di dalam alam semesta. Artinya, manusia adalah bagian dari alam semesta itu sendiri yang hidup bersama dan berdampingan dengan makhluk lain dan organisme lainnya yang tindakan satu sama lain berpengaruh terhadap satu sama lain. ${ }^{14}$ Dibandingkan dengan seluruh isi alam semesta, manusia dan seluruh dimensi alam semesta tidak mengenal konsep

\footnotetext{
13 Mark Olssen, Michel Foucault: Materialism and Education (London, New York: Routledge, 2016), 19.

14 Frederick Steiner, Humans Ecology: How Nature and Culture Shape Our World (Washington DC: Island Press, 2016), 1.
} 
superioriatas makhluk yang satu terhadap yang lainnya. Dengan kata lain, di hadapan alam manusia tidak mutlak menjadi superior. Benar bahwa ada anggapan yang menyatakan manusia sebagai "makhluk sempurna" berkat struktur diri yang mempunyai akal budi untuk memertimbangkan dan meneliti manfaat alam semesta untuk memermudah hidup manusia. Akan tetapi perlu dilontarkan pertanyaan, apakah dengan akal budi itu berarti manusia menjadi superior di hadapan alam semesta? Bukankah rasa superior yang melenyapkan kesadaran bahwa manusia adalah bagian dari alam? Atau bukankah dengan anggapan superioritas manusia berkat akal budi justru membuat manusia seolah-olah terpisah dan menjadi seolah bukan dari alam semesta?

Apa yang superior di dalam alam semesta adalah alam semesta itu sendiri. Sebab alam mempunyai hukum sendiri yang mengodratkan bahwa seluruh bagian yang hidup di dalam alam harus menaatinya, termasuk manusia. Itulah yang superior yang sesungguhnya di dalam alam. Alam semesta bermain dengan hukumnya sendiri. Hukum alam semesta itulah yang diikuti dan ditaati oleh seluruh isinya. Hukum alam menuntut semua isinya membentuk diri untuk beradaptasi dengan hukum alam. Siapa yang dapat mengadaptasi diri dengan alam semesta maka ia dapat diterima dan hidup dalam alam semesta. Manusia hanyalah salah satu bagian kecil di dalam alam semesta dan ia juga berkodrat taat terhadap alam semesta. Alam semesta tidak membutuhkan manusia, manusialah yang justru membutuhkan alam semesta, sebab tanpa manusia alam semesta tetaplah alam semesta, akan tetapi manusia tidak dapat hidup tanpa alam semesta.

Kodrat manusia sebagai bagian dari alam mengandaikan manusia taat atas hukum dan ritme alam semesta. Bagaimana manusia itu hidup ditentukan oleh kualitas ketaatan manusia terhadap ritme dan hukum alam. Apabila manusia taat atas hukum dan ritme alam maka ia hidup, akan tetapi apabila manusia melawan hukum dan kodrat alam (contra natura) maka tindakan itu akan melemparkan manusia pada penderitaan, 
bahkan kematian. Alam semesta dengan hukum dan ritmenya superior di hadapan seluruh isi alam semesta, termasuk manusia. Meminjam gagasan Baruch Spinoza yang menyatakan bahwa alam adalah Allah (Deus sive natura), apa yang muncul dalam alam semesta adalah pancaran keilahian, apa yang alamiah itu adalah kesucian Allah. ${ }^{15}$ Manusia di hadapan alam semesta adalah makhluk alamiah, artinya bagian dari alam semesta yang berkodrat tunduk pada alam semesta. Mengikuti irama, hukum dan ritme alam semesta berarti menjadi manusia yang sadar bahwa manusia adalah makhluk alamiah. Oleh karena itu, sifat dasar cara hidup manusia harusnya berada dalam lingkup irama alam semesta, artinya manusia harus menghormati dan menaati hukum dan ritme alam.

Kesadaran bahwa manusia adalah bagian dari alam dan makhluk alamiah perlahan mulai hilang, sebab dengan kemampuan akal budinya manusia berikhtiar untuk keluar atau melepaskan diri dari, bahkan mengatasi, kodrat dan hukum alam semesta. Perkembangan pesat peradaban teknologi termasuk komputerisasi yang bersifat saintifik, mengembangkan dan memermudah hidup manusia sekaligus menjauhkan bahkan mengasingkan manusia sebagai makhluk alam semesta. Dalam ikhtiar itu manusia kehilangan identitasnya sebagai makhluk alamiah. Dalam situasi itu manusia mengalami kevakuman dan kehampaan eksistensial. Itulah situasi manusia hari-hari ini, yang ditandai dengan kekosongan eksistensial (the age of anxiety). ${ }^{16}$ Celakanya,

\footnotetext{
15 Marjorie Grene dan Debra Nails, Spinoza and The Sciences (Dordrecht: Reidel, 1986), 280.

16 Beberapa ahli sejarah, di antaranya Haynes Johnson dan Arthur Schlesinger, menyebut abad kedua puluh sampai saat ini sebagai the age of anxiety atau masa kecemasan. Søren Kierkegaard menyebutnya sebagai "Existential Angst" atau kecemasan eksistensial, Paul Tillich menyebutnya sebagai "Anxiety of Meaningless" atau kecemasan atas ketakbermaknaan. Tema ini juga telah diekspresikan di dalam syair W.H. Auden dan orkestra Leonard Bernstein. Lih. Helen Blair Simpson (ed.), Anxiety Disorders Theory, Research and Clinical Perspective (Cambridge: Cambridge University Press, 2010), xiii. Fenomena ini melukiskan manusia ada dalam kehampaan dan kekosongan eksistensial, kehilangan kebermaknaan akan sesuatu, manusia kehilangan identitas dan hidup akhirnya adalah ikhtiar untuk mendapatkan diri yang hilang itu.
} 
kekosongan dan kehampaan eksistensial yang disebakan oleh manusia yang hendak keluar dari kodratnya sebagai makhluk alamiah itu terjadi akibat ketercengangan manusia atas kemampuan akal budi mendominasi alam semesta untuk memermudah hidup manusia. Manusia mengalami hilangnya jati diri sebagai makhluk alam semesta dan hendak mencarinya kembali dengan kesadaran tentang kehilangan tersebut. Lucunya, manusia mencari jati diri yang hilang itu dengan kecerdasan akal budinya, dengan membuat alat canggih untuk membelah lautan, meratakan gunung, menutup sungai, bahkan menghilangkan konsep ruang dan waktu, tanpa sadar ternyata jati diri yang hilang tersebut ada di pelupuk mata.

Peradaban saintifik dan teknologis hasil kreativitas dan kekuatan akal budi manusia sadar tidak sadar juga diikuti dengan sikap perlawanan terhadap hukum ruang dan waktu. Dengan cara hidup yang serba teknologis, manusia menjungkirbalikkan dan menguasai kodrat alam semesta dan menghilangkan sendiri jati diri manusia sebagai makhluk alamiah, dan akhirnya mencarinya kembali, tetapi dengan sikap perlawanan terhadap kodratnya. Manusia mendewakan percepatan, menghapus waktu dan jarak, melahirkan budaya instan, bahkan mendominasi dan mengendalikan kodrat alam yang lambat dalam proses, mengubahnya dalam kultur speedaholic. Celakanya, manusialah yang justru ditangkap dan dipenjara oleh penemuan dan pembentukan peradaban mutakhir yang diciptakan sendiri. Realitas saat ini, dalam kaitannya dengan relasi manusia dan alam semesta, persis seperti "orang mabuk", nyaman dalam diri sendiri, seraya tak peduli pada apa yang ada di sekitarnya. Manusia mabuk dengan percepatan yang ditawarkan oleh peradaban teknologis, mereduksi alam semesta sebagai penyedia kebutuhan perkembangan manusia, melupakan superioritas alam dan keterikatan serta keterkaitan manusia dengan alam, mengatasi kodrat dan hukum alam, tanpa melihat realitas yang akan datang dari perilaku manusia terhadap alam, dan ketika alam membutuhkan waktu untuk berevolusi melalui banjir, tsunami, longsor, pemanasan global, gempa 
bumi, dan lain sebagainya, persis pada saat itu juga manusia seperti burung unta yang menyembunyikan kepalanya di dalam pasir ketika muncul bahaya.

Kelambatan adalah kodrat alam semesta. Akan tetapi kelambatan dalam konteks alam semesta tidak melulu berarti kegagalan. Kelambatan alam adalah kehendak baik alam untuk memberikan kehidupan bagi manusia. Hukum alam semesta mengandaikan sikap taat dan tunduk pada proses, dan proses itu logis. Seperti halnya ayam butuh waktu untuk memroduksi telur, padi yang membutuhkan waktu untuk menjadi beras, sapi yang membutuhkan waktu untuk bertumbuh dan lain sebagainya. Logika proses perkembangan dan pertumbuhan alam membutuhkan waktu yang dari sisi manusia cenderung dianggap lambat, dan itu yang coba diatasi dan dilawan oleh perkembangan manusia. Cara hidup yang berubah dan kultur percepatan yang melingkupi semua manusia seolah memaksa manusia untuk memersingkat waktu ayam bertelur, memersingkat waktu padi berubah menjadi beras, dan menjadikan semuanya serba instan dan cepat. Mengubah wujud dari hakikatnya, persis itulah yang dikejar. Hakikat yang direduksi dengan wujud artifisial yang sesuai dengan kegemaran dan selera manusia modern justru merusak dan menyalahi apa yang hendak diberikan alam semesta bagi manusia. Apa yang hendak diberikan oleh alam semesta bagi manusia adalah kehidupan melalui apa yang ada di alam ini, tetapi manusia melihat itu lambat, dan tanpa refleksi mendalam mencoba memberi ramuan percepatan untuk apa yang diberikan alam. Ketika itu disalahi maka yang diberikan alam berubah menjadi penderitaan, penyakit dan bukan lagi kesehatan dan kehidupan. Apa yang serba instan justru memberikan penderitaan bagi manusia, dan manusia dengan bangga dan bahagia menyantap segala sesuatu yang instan itu, meski ia akan mengakibatkan penyakit dan penderitaan. Kemajuan peradaban mutakhir dirayakan, sakit dan penderitaan hendak dihilangkan, tetapi dengan cara keluar dari jalur logika kodrat alam. Maka, manusia menjadi gamang, bingung, hampa 
dan kosong, sebab menyalahkan kodrat alam yang lambat, tak lagi relevan, seraya tetap merayakan kebanggaan peradaban. Di situlah manusia mengalami kepribadian yang terpecah, tarik-menarik dalam kebingungan hendak kembali kepada kodrat alamiah atau tetap pada kegemilangan peradaban teknologis yang menawarkan budaya instanisasi dan percepatan. Ketika kegamangan itu tak dapat dilepaskan, yang muncul kemudian adalah kebrutalan dan kebuasan manusia yang melihat semua yang di sekitar manusia sebagai ancaman, termasuk manusia lainnya dan bahkan Tuhan, di situlah terjadi dehumanisasi. Manusia menganggap semua dapat dimanipulasi, direkayasa dengan frontal dan kotor. Kebutuhan akan beras yang tak lagi cukup, diubah menjadi beras plastik, telur yang tak lagi cukup diubah menjadi telur racikan teknologisasi. Semua kebutuhan tetap diupayakan ada dan cepat melalui kejayaan peradaban teknologis, kendati isinya manipulasi. Singkatnya, manusia menjadi bukan manusia (dehumanisasi) ketika ia mengejar dan mendominasi apa yang tak dapat dikejar oleh batasan kodratnya. Dari sanalah muncul kebiadaban peradaban dan dehumanisasi.

\section{Rekonstruksi Paradigma atas Lingkungan Hidup}

Menalar berbagai fenomena perkara relasi manusia dengan lingkungan hidup tampak seperti masuk ke dalam labirin yang tak berujung. Artinya, masalah lingkungan hidup adalah masalah kompleks. Mencari akar permasalahan lingkungan hidup mirip dengan mencari arloji di dalam tumpukan jerami. Untuk menemukan arloji tersebut bukan hanya memerlukan aksi, melainkan yang tidak kalah penting adalah refleksi dan permenungan yang mendalam. Diam dan mendengarkan serta merenungkan apa yang mau dikatakan oleh alam semesta. Demikian halnya mencari arloji di tumpukan jerami kita membutuhkan suasana hening, diam dan fokus untuk mendengarkan dan menemukan bunyi suara arloji yang berdetak. Tentang masalah yang terakhir ini, banyak orang cenderung tidak punya waktu untuk merenungkannya, sebab 
manusia saat ini dituntut untuk berlari cepat memenuhi kebutuhan produksi dan lupa atau tidak ada waktu untuk itu. Karenanya, dalam bagian berikut akan ditawarkan suatu cara pandang yang bisa jadi dapat memberikan sumbangsih untuk membangun kembali kesadaran akan pentingnya merekonstruksi cara pandang terhadap lingkungan hidup sebagai tawaran refleksi filosofis dan teologis.

\section{Tawaran Refleksi Filosofis dan Teologis}

Filsafat muncul dari pertanyaan tentang segala sesuatu. Adalah Thales filsuf pertama yang merefleksikan siapa itu manusia dan alam semesta. ${ }^{17}$ Pertanyaan-pertanyaan filosofis berangkat dari kekaguman atas fenomena alam semesta yang besar dan indah. Dari pengalaman itu manusia mulai merenungkan siapa dirinya. Refleksi filosofis berperan besar membentuk sejarah dan peradaban manusia. Kiblat dasar refleksi filosofis adalah kebenaran, kebaikan dan keindahan (Verum, Bonum, Pulchrum). Hari-hari ini, refleksi filosofis ditantang untuk mencoba menjawab permasalahan ekologis karena lama sekali refleksi filosofis pun bernuansa antroposentris. Dari kecenderungan itu pula muncul kebutuhan untuk memperluas kajian etika sebagai cabang filsafat yang cenderung puas hanya berbicara tentang kepentingan manusia. Dari rasa krisis terhadap kemandekan etika yang hanya mengurusi manusia, muncullah etika ekosentris yang berusaha menawarkan cara pandang tentang alam semesta.

Etika ekonsentris lahir dari kebutuhan mendesak untuk menjawab persoalan-persoalan ekologis. Tujuannya adalah membangun kesadaran bahwa seluruh yang ada di alam semesta ini membutuhkan pertimbangan moral dalam usaha memecahkan dilema-dilema etis untuk menjawab persoalan-persoalan ekologis. Etika ekosentris berkembang dari laju etika yang cenderung berpusat pada manusia. Misalnya, etika egosentris. Etika yang egosentris berikhtiar bahwa setiap individu

17 Kees Bertens, Sejarah Filsafat Yunani, 33. 
mempunyai hak untuk mengembangkan dan menyejahterakan hidup pribadi. Paradigma ini berakar pada prinsip bahwa kesejahteraan pribadi akan membentuk kesejahteraan masyarakat. Etika jenis ini berkembang pada abad ketujuh belas. Motivasi dasar atau prinsip etika jenis adalah menimba dan meraup sabanyak mungkin keuntungan dan manfaat bagi diri sendiri. Landasan filosofis etika jenis ini berangkat dari pemikiran Thomas Hobbes. Bagi Hobbes, manusia pada dasarnya adalah makhluk yang kompetitif. Manusia sebagai makhluk rasional sekaligus mempunyai aspek instingtif yang dekat dengan kebinatangan. Artinya, manusia dapat menjadi serigala dan memangsa manusia lainnya (homo homini lupus). Maka dari itu, secara kodrati manusia akan bersaing atau berkompetisi untuk memperluas wilayah dan mengolah lahan demi kepentingan pribadi. Prinsip dasarnya, manusia mempunyai hak yang sama dengan semua manusia lainnya, yaitu berhak untuk memenuhi kebutuhan dan menyejahterakan diri pribadi. Alam semesta dalam cara pandang ini dilihat sebagai penyedia atau bahkan lahan pertarungan pemenuhan hak dan kebutuhan pribadi manusia. Sebab itu, alam dapat dikuras dan diolah sebanyak-banyaknya dan seluas-luasnya demi kebutuhan. Oleh karena kodrat manusia yang kompetitif tersebut, dibutuhkan hukum yang mengatur pertarungan manusia dalam usaha memenuhi kebutuhan pribadinya. Tujuannya adalah untuk menghindari keadaan krisis yang terjadi dalam pertarungan kesejahteraan tersebut. Dalam bukunya, Leviathan, Hobbes menyatakan pentingnya negara dengan perangkat sistemnya untuk membuat aturan hukum yang mengatur pertarungan kodrati manusia yang kompetitif. Kelemahan utama dalam etika yang egosentris adalah tidak tersedianya ruang permenungan terhadap dampak ekologis oleh sebab tuntutan ekonomis. Selain itu, etika yang muncul pada abad ketujuh belas ini cenderung banyak menciptakan kesenjangan karena bermain dalam skema the winner and the loser, yang tangguh dan yang kuat berkompetisi menjadi 
pemenang, dan yang lemah adalah yang kalah. Berangkat dari persoalan yang terakhir ini, lahirlah etika yang homosentris. ${ }^{18}$

Etika yang homosentris atau yang sering juga disebut sebagai etika yang antroposentris bersandar pada prinsip pentingnya untuk menciptakan kesejahteraan dan kebaikan bersama (Bоnит Commune). Tempat aplikasi etika ini ada di wilayah kehidupan sosial. Prinsip etis dari etika ini adalah bahwa setiap individu bertindak dan berperilaku demi menciptakan dan terselenggaranya kebaikan dan kesejahteraan bagi semakin banyak orang. Menciptakan kesejahteraan umum menjadi tujuan bersama dan mereduksi penderitaan dan kesengsaraan umum menjadi tugas bersama. Meminjam istilah Emmanuel Levinas yang mengungkapkan bahwa manusia bertanggung jawab atas nasib manusia lainnya (Responde Ergo Sum: saya bertanggung jawab maka saya ada), ukuran dari kebaikan moral adalah terciptanya kesejahteraan bersama, itu sebabnya etika jenis ini disebut juga dengan istilah utilitarianisme, yakni prinsip kemanfaatan dan kesejahteraan bersama bagi sebanyakbanyaknya orang. Singkatnya, etika jenis ini termuat dalam kaidah emas yang berbunyi "Perlakukanlah orang lain seperti kita sendiri memperlakukan diri sendiri", atau dalam nuansa negatif, "jangan lakukan kepada orang lain apa yang tidak ingin kita lakukan pada diri kita sendiri". ${ }^{19}$

Seiring berkembangnya peradaban, laju etika juga terus berkembang dari egosentris ke homosentris dan etika ekosentris. Etika ekosentris lahir dari keprihatinan terhadap dampak perilaku manusia terhadap alam semesta. Etika egosentris dan homosentris dianggap tidak cukup untuk menjawab persoalan-persoalan yang muncul dalam kaitannya dengan alam semesta. Kesadaran ini muncul beriringan dengan kesadaran bahwa manusia adalah makhluk alam yang tidak bisa

\footnotetext{
18 Bambang Sugiharto dan Agus Rahmat, Wajah Baru Etika dan Agama (Yogyakarta: Kanisius, 2000), 60.

19 Ibid., 68-72.
} 
lepas dari alam. Adalah Aldo Leopold (1930-1940) yang pertama kali merintis etika ekosentris. Aldo Leopold menimbang pentingnya etika untuk membuat terobosan baru dalam kaitannya dengan lingkungan hidup. Etika ekosentris berusaha menanamkan paradigma kesatuan dan saling keterkaitan antara manusia dengan alam. Tujuannya adalah membangun paradigma bahwa setiap entitas alam semesta mempunyai nilai intrinsik di dalam dirinya sendiri. ${ }^{20}$

Etika ekosentris memberikan sumbangsih yang berarti, terutama dalam pembentukan cara berpikir manusia terhadap lingkungan sekitarnya. Kesadaran dan gerakan bermunculan dari skala lokal maupun global, misalnya saja sejak tahun 1980 sudah ada gerakan di level internasional World Charter of Nature pada tanggal 28 Oktober 1980. Di skala lokal, misalnya gerakan penyadaran di bidang pendidikan, gerakan kearifan lokal untuk menjaga kelestarian alam. Artinya, manusia sadar terhadap kerusakan lingkungan hidup dan mau bergerak untuk mengatasi masalah lingkungan hidup. Akan tetapi perlu dikritisi: apakah kesadaran akan lingkungan hidup muncul dari kesadaran bahwa manusia memandang entitas alam semesta bernilai dalam dirinya sendiri? Atau justru kesadaran manusia akan lingkungan sekitarnya mempunyai karakter antroposentris? Apakah kesadaran lingkungan hidup itu berangkat dari sisi manfaat lingkungan hidup bagi manusia?

Gagasan etika ekosentris menekankan bahwa elemen alam semesta itu tanpa terkecuali bernilai di dalam dirinya sendiri. Artinya, etika ekosentris mencoba mendobrak pemikiran dualisme subjek-objek dalam memandang alam semesta. Alam dianggap sebagai objek pemenuhan kebutuhan manusia, sehingga memunculkan distansi atau pembedaan antara manusia dan yang bukan manusia; juntrungannya, yang bukan manusia dianggap lebih rendah bahkan dipandang sebagai barang yang relasinya ditentukan oleh paradigma pragmatis dari sisi antroposentris. Pembedaan ini akan melahirkan paradigma pemisahan antara manusia

$20 \quad$ Ibid., 74 . 
dan alam semesta, atau manusia menegasi kenyataan bahwa manusia dan alam saling terkait satu sama lain. Untaian sikap demikian bersumber dari rahim paradigma mekanistis yang memandang alam semesta sebagai mesin besar yang elemennya berdiri sendiri dan tidak saling terkait satu sama lain. Ada banyak gerakan dan ada banyak kesadaran, semua itu bisa jadi hanya klise yang lagi-lagi hanya menempatkan manusia dalam posisi pusat. Artinya, kesadaran itu tidak mendalam dan bisa jadi dangkal.

Akar masalah ada dalam cara pandang yang dibangun yang justru memisahkan, membedakan, dan sikap yang muncul adalah dominasi. Apabila cara pandang ini belum dibangun di dalam diri manusia, gerakan dan kesadaran bahkan kebijakan politis tentang lingkungan hidup hanya dipandang dari sisi antroposentris saja. Refleksi filosofis terhadap perkara lingkungan hidup mau melawan cara pandang ini dan membangun paham yang lebih holistik dan relasional. Dengan kata lain, tawaran refleksi filosofis membangun argumentasi yang kokoh bahwa alam itu bernilai dalam dirinya sendiri, dan setiap elemen alam semesta mempunyai hak eksistensi. Sungai mempunyai hak untuk mengalir, pohon mempunyai hak untuk tumbuh dan bercabang, binatang dan tumbuhan juga mempunyai hak eksistensi. Kesadaran itu harusnya dilihat dalam relasi yang saling terkait di dalam alam, bahkan juga di dalam manusia, sehingga manusia tidak hanya melihat dan menilai alam dari perspektif manusia, melainkan memandang alam sebagai subjek yang juga bernilai dan menentukan hidup manusia.

Perkembangan gerakan ideologis, politis, ilmu pengetahuan harihari ini dituntut untuk mencantumkan tema lingkungan hidup dalam agenda terutama menempatkan visi revolusi paradigma terhadap alam semesta yang mendasari seluruh wacana keputusan dan kebijakan. Visi ini telah tampak dari sisi ilmu pengetahuan, misalnya dari bidang fisika yang menggeser cara pandang dari mekanistis ke teori quantum yang memandang alam semesta sebagai wilayah yang riil; dengan kata lain, realitas itu adalah bidang yang diisi berbagai elemen yang saling 
berkaitan dan berhubungan satu sama lain. Artinya, satu elemen dalam alam semesta mempunyai hubungan dampak tertentu bagi elemen lainnya bagi alam semesta atau elemen alam semesta mempunyai keterkaitan saling bergantung pada bagian-bagian elemen alam semesta satu sama lain.

Fritjof Capra menyebutnya sebagai prinsip Web of Life. Prinsip ini menjelaskan bahwa setiap bagian dalam alam semesta ini saling terkait satu sama lain dengan kompleksitasnya masing-masing, setiap entitas berkembang bertumbuh berdasarkan jati dirinya masing-masing dan saling memengaruhi perkembangan kehidupan entitas lainnya. Setiap entitas mempunyai hak untuk eksis, hidup, dan berkembang; artinya setiap entitas itu alam semesta termasuk manusia mempunyai batasbatas identitas yang harus dihormati eksistensinya, sebab semua entitas tersebut saling mendukung dan terkait satu sama lain. ${ }^{21}$ Batas tidak untuk memisahkan, melainkan membangun paradigma nilai dalam setiap entitas, karena dasar kenyataan adalah bidang yang di dalamnya ada jejaring yang saling menghidupkan, melengkapi, dan menyelamatkan. Ini berbeda dengan paradigma mekanistis yang berpusat pada paham bahwa alam semesta adalah mesin raksasa yang dimainkan dalam bagian-bagian, sehingga setiap bagian harus berkompetisi untuk tetap hidup, dan celakanya manusia dianggap sebagai mesin terbaik yang seolah layak mengontrol berjalannya mesin raksasa ini. Pergeseran dari mekanistik ke paradigma jejaring memberi harapan bagi kebaikan lingkungan hidup.

Refleksi teologis tidak kalah penting dalam memberikan sumbangsih terhadap perkara lingkungan hidup. Benih kepedulian itu ada, sebab salah satu agenda utama dalam agama adalah refleksi teologis yang berusaha memertahankan keutuhan ciptaan. Kelestarian lingkungan hidup adalah tugas penting para teolog dan agamawan. Sayangnya, refeleksi teologis cenderung cepat puas hanya membicarakan

21 Sonny Keraf, Filsafat Lingkungan Hidup: Alam Sebagai Sebuah Sistem Kehidupan, 138. 
relasi manusia dengan Tuhan, dan Tuhan dengan manusia. Bahkan refleksi teologis cenderung sibuk dengan afirmasi doktrin daripada bertualang menemukan kebenaran kritis dalam konteks tertentu. Memang sejatinya teologi adalah disiplin ilmu yang berbicara tentang Allah, atau lebih tepatnya adalah usaha metodis untuk menafsirkan kebenaran wahyu. ${ }^{22}$ Akan tetapi, melihat selayang pandang, situasi dekadensi moral yang akut, korupsi, kekerasan, bahkan kerusakan lingkungan dibalut latar kekuasaan dan mammon masih terus membelenggu kehidupan di negeri ini. Teologi harusnya beranjak dari kungkungan eksplorasi wahyu saja, refleksi teologis harus berkonteks, masuk ke dalam seluk-beluk kelindan pertikaian dan kegaduhan serta keberpihakan pada lingkungan hidup. Di situlah teologi bisa menemui relevansinya dan karena itu juga teologi masih diakui kalau tidak mau mati. ${ }^{23}$ Refleksi teologis harus bergerak dari eksplorasi yang hanya berpusat pada relasi yang ilahi dengan manusia, terutama kepada keadaan lingkungan hidup saat ini menantang refleksi teologi untuk melakukan refleksi ulang.

Refleksi teologis sudah berusaha memberikan tawaran terhadap perkara lingkungan hidup yang dihadapi manusia hari-hari ini. Akar masalah tidak lain adalah sikap egoistik-antroposentrik, paradigma yang mekanistik, dan cara pandang pragmatik terhadap alam semesta. Akan tetapi mencoba menawarkan sebuah deklarasi keprihatinan bersama terhadap lingkungan hidup, seolah dapat menjadi bumerang bahkan bagi sumber teologi itu sendiri. Teologi saat ini diinstitusikan dalam agama, itu sebabnya teologi tidak bisa netral, artinya teologi mengandaikan adanya iman. Kita tahu bahwa paradigma teologis itu plural dan beragam, entah dari agama tertentu maupun para teolog

\footnotetext{
22 Teologi (Yunani: 'Pengetahuan mengenai Allah'). Usaha metodis untuk memahami serta menafsirkan kebenaran wahyu. Teologi menggunakan sumber daya rasio khususnya ilmu sejarah dan filsafat. Lih. Gerald O'Collins dan Edward G. Ferrugia, Kamus Teologi (Yogyakarta: Kanisius, 1996), 314.

23 G. Pattison, The End of Theology and Task of Thinking about God (London: SCM Press, 1998), 91.
} 
tertentu. Efek buruk keragaman ini seolah mendorong refleksi teologi hanya berperkara pada pemajangan dogma-dogma untuk ditawarkan, umumnya karena mengejar kuantitas. Pertikaian antara bendera teologis belum selesai, meski semua tradisi teologis dalam agama mempunyai pandangan yang dalam tentang lingkungan hidup. Bisa jadi kerusakan lingkungan hidup adalah masalah matinya animisme di Indonesia. Banyak pemajangan dogmatisme yang aman bahkan berkompetisi, hingga bahkan menegasi yang lain yang dianggap tidak merepresentasikan relasi manusia dengan yang ilahi. Animisme, kalau mau dikatakan memuat cara pandang teologis, tentu benar, karena di balik keyakinan adanya anima atau jiwa di balik pohon maupun sesuatu, ada yang dianggap sakral sebagai representasi yang ilahi hadir ke dalam hidup manusia. Akan tetapi animisme di"kafir"kan dalam pertarungan teologis itu. Sehingga berkuranglah paradigma sakralitas alam. Berlian yang ada di dalam cara pandang animisme adalah sakralitas alam. Ini yang hilang, bisa jadi karena pertarungan teologis.

Refleksi teologis hendaknya mencanangkan kembali berlian tersebut. Paradigma sakralitas alam memunculkan rasa kagum dan rasa tunduk dan hormat, karena alam adalah representasi yang ilahi. Cara pandang seperti ini tidak melulu bernuansa politeis atau tidak hanya milik gagasan politeis. Manusia secara sadar tentu tidak bisa lepas dari alam, karena ia adalah makhluk alam. Rasa kesatuan dengan alam dan relasi yang saling terkait dibekali oleh cara pandang bahwa alam itu sakral, maka ketika manusia mengotorinya dan bahkan merusak serta mendominasi karena nafsu tak terkendali, di situ pula manusia menolak sakralitas dirinya sebagai makhluk alam dan bahkan menolak kenyataan bahwa dia adalah makhluk alam yang harus tunduk pada alam. Apabila ada penyangkalan maka penderitaan bahkan kematian adalah ganjaran.

Oleh karenanya, refleksi teologis harus rileks terhadap doktrin dan bertualang menemukan solusi yang jitu untuk lingkungan hidup. J. Moltmann menawarkan suatu cara pandang yang ekumenis dalam memandang siapa itu manusia dan alam semesta. Dia menggunakan 
istilah ekumene yang menunjuk pada arti bahwa alam semesta ini adalah rumah tinggal bersama, dihuni oleh semua entitas alam semesta, dan tugas manusia adalah membuat rumah bagi semua penghuni alam semesta ini termasuk yang berbeda dengan manusia menjadi tempat tinggal yang layak dihuni, nyaman dan damai. Moltmann menawarkan spiritualitas kesatuan realitas, bahwa realitas yang satu adalah bumi dan isinya yang hidup dan tinggal bersama menuju pada kesempurnaan. Maka, segala yang berbeda dengan manusia di alam semesta ini tidak dapat dipandang sekadar sebagai objek dalam kacamata utilitas. Lebih lengkap lagi, kita meminjam analogi Sallie McFague, yang menggambarkan alam semesta ini sebagai tubuh Allah (The Body of God), dan Allah adalah Roh yang memberi kehidupan bagi dunia ini. Inspirasi kedua tokoh tadi menawarkan suatu cara pandang kesatuan manusia dengan alam semesta yang menekankan bahwa manusia adalah makhluk alam yang saling terkait satu sama lain dengan seluruh isi alam semesta ini. Spiritualitas demikian mendorong manusia untuk menghapus paradigma yang melihat dirinya terpisah dari alam sehingga tidak semena-mena mendominasi alam dan merusak alam. Dalam konsep ekumenis manusia menyadari bahwa ia adalah makhluk alam yang menyadari bahwa ia saling terkait dengan seluruh bagian alam semesta ini. Manusia membedakan diri dengan entitas lainnya tetapi tidak melepaskan diri dan bahkan tidak memisahkan diri dari alam. ${ }^{24}$

Perkara lingkungan hidup dari refleksi filosofis dan teologis bukanlah masalah yang mudah diselesaikan. Ada banyak filsuf dan teolog, yang tidak bisa semua dimasukkan di sini, memunculkan berbagai gagasan mengenai lingkungan hidup dan tawaran solusi-solusi pemecahan masalah. Perkara ekologis bukan sekadar perkara yang mau menjawab "bagaimana" (how), tetapi lebih pada menjawab "mengapa" (why). Pertanyaan "mengapa" memberikan kesadaran bahwa alam

\footnotetext{
24 Leo Samosir, Agama dengan Dua Wajah: Refleksi Teologis atas Tradisi dalam Konteks (Jakarta: Obor, 2010), 148.
} 
semesta-meskipun ia independen-bisa jadi dia mau berbisik kepada manusia bahwa manusia adalah bagian dari setiap entitas di dalam alam semesta ini. Bisikan itu mungkin juga ajakan pertobatan radikal. Penanggulangan masalah ekologis harus diawali dengan metanoia total dengan spirit dan cara pandang baru dalam berelasi dengan alam semesta. Perubahan gaya hidup, penolakan pemikiran distingsi dan distansi terhadap alam semesta, pendidikan lingkungan hidup yang melawan budaya konsumerisme, materialisme, individualisme, pragmatisme dan kesadaran bahwa pertobatan ekologis, adalah panggilan bagi semua manusia untuk masuk dalam pertobatan batin yang mendalam dan yang menumbuhkan semangat pelestarian dunia. ${ }^{25}$

25 Bdk. Martin Harun, Ensiklik Laudati Sri Paus Fransiskus (terj.), 161. 